\title{
A Solar Panel Cleaning Robot Design and Application
}

\author{
Omur Akyazi $^{1 *}$, Erdinc Sahin ${ }^{2}$, Timur Ozsoy ${ }^{3}$, Mehmet Algul $^{4}$ \\ ${ }^{1}$ Karadeniz Teknik Üniversitesi, Of Teknoloji Fakültesi, Enerji Sistemleri Mühendisliği Bölümü, Trabzon, Türkiye (ORCID: 0000-0001-6266-2323) \\ 2 Karadeniz Teknik Üniversitesi, Of Teknoloji Fakültesi, Enerji Sistemleri Mühendisliği Bölümü, Trabzon, Türkiye (ORCID: 0000-0002-9740-599X) \\ ${ }^{3,4}$ Karadeniz Teknik Üniversitesi, Of Teknoloji Fakültesi, Enerji Sistemleri Mühendisliği Bölümü, Trabzon, Türkiye \\ (This publication has been presented orally at HORA congress.)
}

(First received 1 August 2019 and in final form 25 October 2019)

(DOI: $10.31590 /$ ejosat.638291)

ATIF/REFERENCE: Akyazı, Ö., Şahin, E., Özsoy, T. \& Algül, M. (2019). A Solar Panel Cleaning Robot Design and Application. European Journal of Science and Technology, (Special Issue), 343-348.

\begin{abstract}
Solar energy, which is one of the renewable energy sources, has an important role in meeting the increasing electrical energy demand of our globe. In recent years, many countries have established their energy policies based on solar energy, and researchers have been working on solar panel efficiency, maximum energy extraction from the sun, control and power electronics. The energy extracting from the sun is converted into electrical energy via solar panels. To extract continuously maximum energy level from the sun reduces installation costs and makes it easier to meet the demanded peak electrical power. Physical conditions such as muddy rain, snow and dusting place between the solar panel and the sun. This situation results the reduced electrical power extraction level which can be technically produced with clean solar panel surface. Therefore, it is also very important to keep the solar panels clean as well as the maximum power point tracking devices. In this study, a solar panel cleaning robot (SPCR) has been designed and tested in real time. The designed dual-motor and crawler robot moves horizontally and the cleaning brush runs on the vertical axis. In addition, the length of the solar panel array can be detected by position switches to keep the SPCR in desired working area.
\end{abstract}

Keywords: Photovoltaic system, Solar panel efficiency, Solar panel cleaning robot, Arduino software development board.

\section{Güneș Paneli Temizleme Robotu Tasarımı ve Uygulaması}

\begin{abstract}
$\ddot{O} \mathbf{z}$
Yenilenebilir enerji kaynaklarından olan güneş enerji, yer küremizin artan elektrik enerji talebinin karşılanmasında önemli bir konuma gelmiştir. Son yıllarda ülkelerin çoğu enerji politikalarını güneş enerjisi tabanlı kurmakta ve araştırmacılar da güneş paneli verimi, güneşten maksimum enerji çıkarımı, denetimi ve güç elektroniği üzerine çalışmalarını sürdürmektedir. Güneşten gelen gelen enerji güneş panelleri yardımıyla elektirik enerjine çevrilmektedir. Panellerden alınan enerjinin sürekli maksimumda tutulması kurulum maliyetini düşürerek talep edilebilecek tepe elektrik gücünün karşılanmasını da daha kolay duruma gelmektedir. Çamur halinde yağan yağmur, kar ve tozlanma gibi fiziksel durumlar panel ile güneş arasına girerek üertilebilecek güç seviyesini azaltmaktadır. Bu nedenle maksimum güç noktası izleyici cihazların yanında güneş panellerinin temiz tutulması da hayli önem arz etmektedir. Bu çalışmada bir güneş paneli temzileme robotu (GPTR) tasarlanmış olup sistemin gerçek zamanlı testleri de yapılmıştır. Tasarlanan çift motorlu ve paletli robot yatay düzlemde hareket ederken temizleme firçası ise dikey eksende çalışmaktadır. Ayrıca konum anahtarları ile güneş paneli dizisinin boyutları algılanarak GPTR istenilen çalışma alanı içinde tutulabilmektedir.
\end{abstract}

Anahtar Kelimeler: Fotovoltaik sistem, Güneş paneli verimi, Güneş paneli temizleme robotu, Arduino yazılım geliştirme kartı. 
${ }^{1}$ Sorumlu Yazar: Karadeniz Teknik Üniversitesi, Of Teknoloji Fakültesi, Enerji Sistemleri Mühendisliği Bölümü, Trabzon, Türkiye, ORCID: 00000001-6266-2323, oakyazi@ktu.edu.tr

\section{Introduction}

Because of imbalance cost, declining reserve and enviromental effects on climate change and carbon emission, fussel oils such as coal, gas and oil are no longer an option in energy production. Also, considering the increasing energy demand in the world, solar power, as a sustainable, renewable and eco-friendly energy alternative, has been expanding all around the globe due to its advantages in both technological and economical aspects. In addtion, it acts as an economical savior for the countries which are highly dependent on foreign countries in terms of energy.

From the perspective of Turkey, total annual insolation time is 7.5 hours per day and the total solar energy obtained from the sun is $4.18 \mathrm{kWh} / \mathrm{m}^{2}$ per day [1]. Also, in Turkey, installed total electrical power capacity (licensed and unlicensed) was nearly $3.42 \mathrm{GW}$ by the end of 2017 . This capacity was updated to $3.95 \mathrm{GW}$ by the end of February 2018 [2]. That means total installed solar power capacity has $15.5 \%$ growth which is a significant increase for our country in the subject of economical problems.

There are two major ways to convert solar energy to electrical energy: photovoltaic solar systems of which directly use the sunlight and the other way is heat based systems. But, solar power is generally produced by photovoltaic panels [3]. Solar panel efficieny which depends on heat and solar irradiation is one of the important topic in order to extract maximum available power from the sun.

Maksimum power point traking (MPPT) devices are one of the way for increasing solar array efficiency by changing equivalent load. These devices are DC-DC converters controlled with MPPT algorithms. Among the MPPT algorithms, Perturb and Observe (P\&O) method and the Incremental Conductance (IC) method are widely used ones [4-6].

Some physical conditions also cause loss of effciency of solar system. One of these condition is shading affect caused by cloudy weather, nearby tree or buldings. A small part of shading occured on solar panels makes a big impact on output power. In [7], authors claimed that under partially shaded conditions, the PV curves have multiple peaks and the existing MPPT schemes remain inadequate. Commissioning and decommissioning of PV systems shaded parts or different connection and configuration types of PV panels a re suggested in literature to minimize shading effect on produced PV power [8,9].

The other condition of reducing PV system efficieny is dust accumulation on PV cells and soiling of PV cells owing to pollen, sand, bird droppings and etc. This situation decreases total system efficiency by preventing solar irradiation to arrive solar panel. The negative effect of talcum, sand and dust on a PV cell current-voltage (I-V) chacteristic is studied in [10] experimentaly. According to [11], analizing the effect of dust accumulation on the power outps of solar modules in real outdoor condition of Dhahran in Saudi Arabia, $50 \%$ decrease in power output could be experienced if cleaning is not performed on modules for a period of time that exceeds six months. In [12], Based on author's study, they recommended a table that has been developed to guide for identifying appropriate cleaning and maintenance period for PV systems inresponse to the prevalent climatic and environmental conditions. Also, in the study [13], an experimental investigation of the impact of airborne dust deposition on the performance of solar photovoltaic (PV) modules is done. Experimental results show that the reduction of efficiency has a linear relationship with the dust deposition density and the dust deposition and accumulation on solar panels causes a significant reduction in short circuit current.

To solve above-mentioned problem, engineers design various type of automatic solar panel cleaining systems. Some of these automatic cleaning systems: Gekko solar robot with the advantage of high cleaning capacity, improved safety and easy handling [14] and Gekko solar farm robot [15] with convincing productivity, variable cleaning width, no additional installations and easy handling by using radio and joystick, Solar brush [16] with quality, cost and environmental advantages, Hector [17] including superiorities such as small size, weight favor, completely autonomous and reduced cost, Sunpower-greenbotic's GB1 [18] which is wireless and rechargeable, Heilotex's automatic cleaning system [19] which is also cooling the PV module and PIC microcontroller and programmable logic controller (PLC) based cleaning systems [20-23]. Also, comparision of installation cost and variable cleaning types for PIC and PLC based systems can be found in [24]. For detailed explanations on history, comparision, shortcomings and advantages of above-mentioned solar panel cleaning systems, the studies [25-27] can be analyzed.

Hereby, we design a cost effective solar panel cleaning system. The software of the system is implemented on Arduino development board. A charge and also park station is available The system moves on PV module both in vertical and horizontal axis. In horizontal axis, robot goes on one panel to another and cleaning brush runs on the vertical axis. The length of the solar panel array can be detected by position switches to keep the SPCR in desired limiting array. The detailed explanations on designed cleaning system is given in following section with the subtitles hardware and software parts.

\section{System Description}

In this project, the cleaning of the dust materials accumulated and formed on the PV panel surface will be facilitated. Control of the device will be provided by microprocessor which is explained detaily in software section. Designed device completes the cleaning process automatically with limit and distance sensors. It will be able to charge the battery in the parking station so that it will be ready for the next washing process without any extra effort. In the movement system, pulley pallet system which is specially designed for the PV panel provide a smooth transition from the gaps between the PV panels. Thanks to this pallet system, there is no need for any additional rail system for PV panels that results in reducing both material and labor costs. Aluminum sigma profiles used as frame and rail system provide the advantage of lightness to the device. The parts used in connections of metarials are filament and the designs are 
produced with 3D printer. By reduced weight and cost of the designed SPCR system, cheap, lightweight, automatic and low maintenance cleaning will be obtained.

\subsection{Software implementation}

The aim of the software part of the project is to control hardware of the system including mechanical components. Generally, microcontrollers and PLC systems are preffered such system control. In our project, we used Arduino nano compact board. The board based on ATmega328 microcontroller with 16Mhz clock speed, 8 number of analog inout pins, 22 digital input-output pins ( 6 of which pulse width modulatin (PWM)), and 5V operating voltage [28]. The reasons why we use Arduino nano are small pcb size $(18 \times 45 \mathrm{~mm})$, $7 \mathrm{~g}$ weight and cost effective. The board has been programmed with a computer program which is an open-source Arduino Software (IDE). The program allows user to write code and upload it to the board easily. It can be download from given link in [29]. The operational flow diagram of the writed code for this project is illustrated in Fig. 1. As seen, the code based on logical decision units YES means logical $1(+5 \mathrm{~V})$ and No means logical $0(0 \mathrm{~V})$.

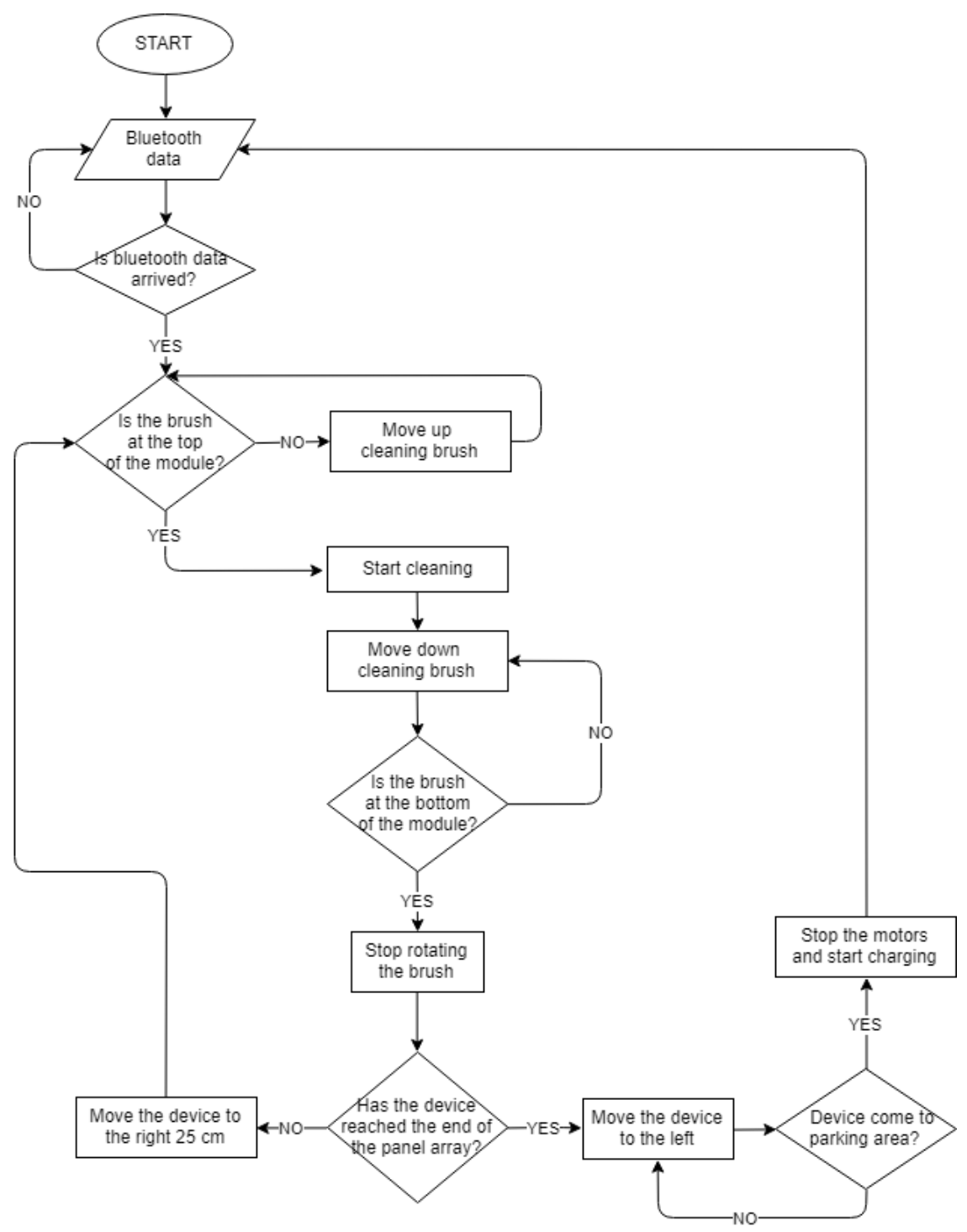

Figure 1. Algorithm flow chart used for SPCR system

\subsection{Hardware implementation}

The hardware schematic representation is shown in Fig. 2. The device will store electrical energy while it is in standby state. When it is activated, the cleaning brush begins to rotate and move down vertically through the PV panel. When cleaining procees of a PV panel is finished, the brush will stop rotating and vertically go up and SPCR moves horizontally to the other PV panel. This cycle continues until the end of the PV array. Then, the device returns to parking station and begins to charge. The device will be charged while waiting for the activation command in parking station where is located at the left side of the PV array. In this manner, shading effect of the SPCR will be also prevented. The photo of the designed SPCR system is illustrated in Fig. 3 with with description of subsystem compenents. 
The vertical movement is the first step of the loop operation. The brush moves circularly with the help of DC motors. As the second step of the cycle, when the cleaning process is finished, SPCR moves to the right side to the next cleaning zone and also, brush moves vertically to the top of the robot. These loops continue until the end of the panels. When the cycle is complete, it returns to the standby station. In Fig. 4, zoomed photos of the subsystems are given.

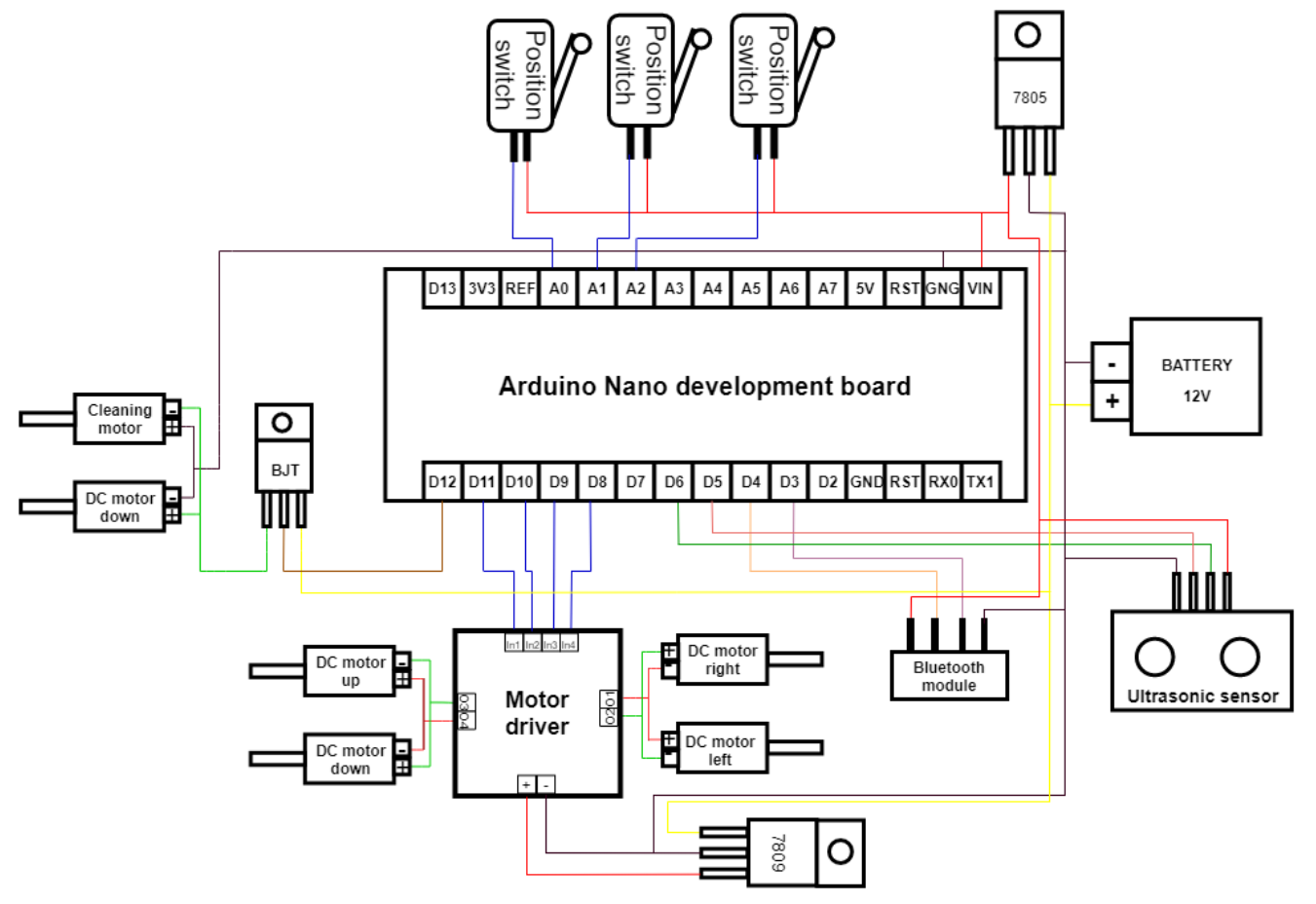

Figure 2. Schemeatic hardware of the designed SPCR. 


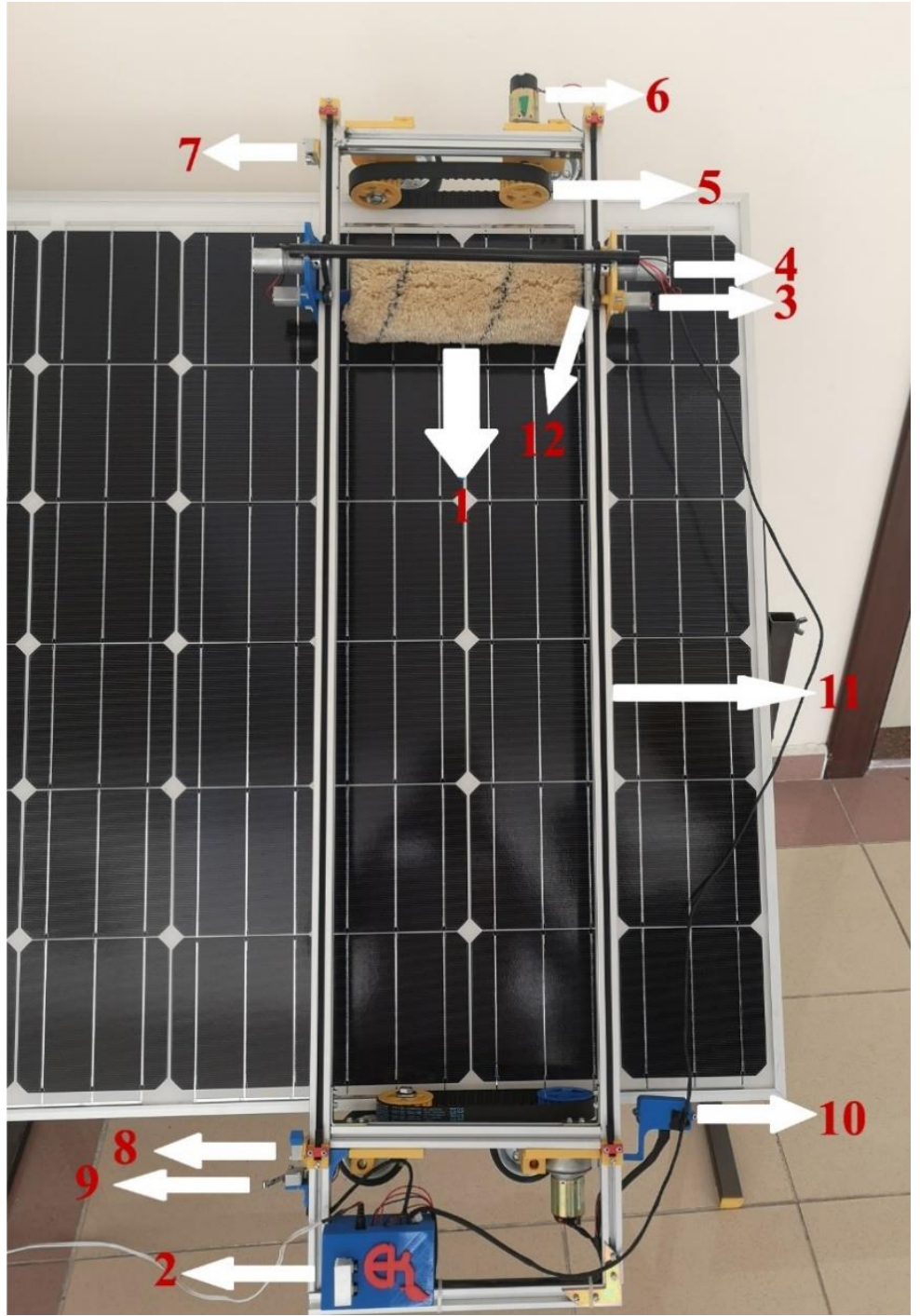

1) Cleaning brush.

2) Control unit

3) $9 \mathrm{~V}$ DC motor for rotating the brush (2 pieces).

4) DC motor that allows the brush to move up and down.

5) Special design pallet. It provides the right and left movement of the device without rail (2 pieces).

6) DC motor for rotating pallets.

7) Limit sensor used to check if the brush is at the top.

8) Limit sensor used to check if the brush is at the bottom.

9) Limit sensor used to check if the device is at the parking/charging station.

10) UItrasonic distance sensor used to check whether the panel array of the device is finished.

11) Rail of the mechanism with up and down movement of the brush.

12) Movement mechanism connected to rail.

Figure 3. Photo of the overall integrated system parts with descriptions.

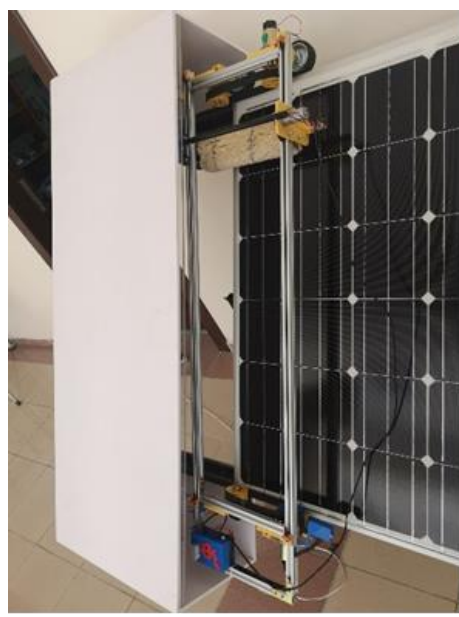

(a)

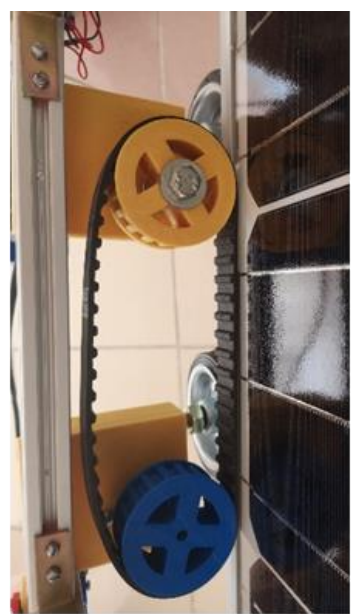

(b)

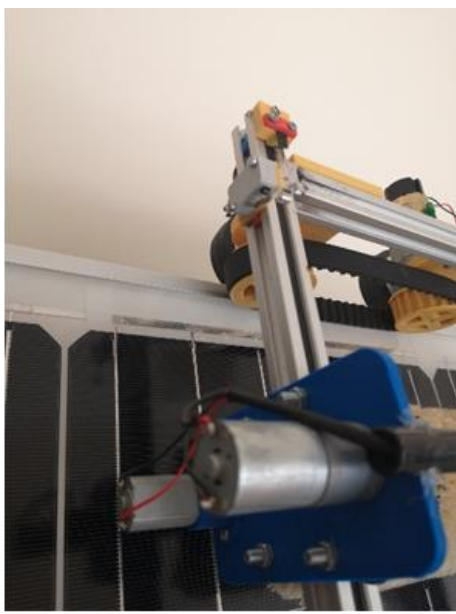

(c)

Figure 4. Photos of the charging station (a), pulley pallet system (b) and DC motors used for rotating and moving the brush (c).

In control unit, shown in Fig. 5, there are Arduino nano development board, motor driver (L298) used to drive DC motors for SPCR horizontal and brush vertical movements, bluetooth module (HC06) used for remotely activation command, voltage regulators 7809 and 7805 used to supply DC $+9 \mathrm{~V}$ and $+5 \mathrm{~V}$ for motors, tansistors used as switches, power input $+12 \mathrm{~V}$ and connetion terminals. 


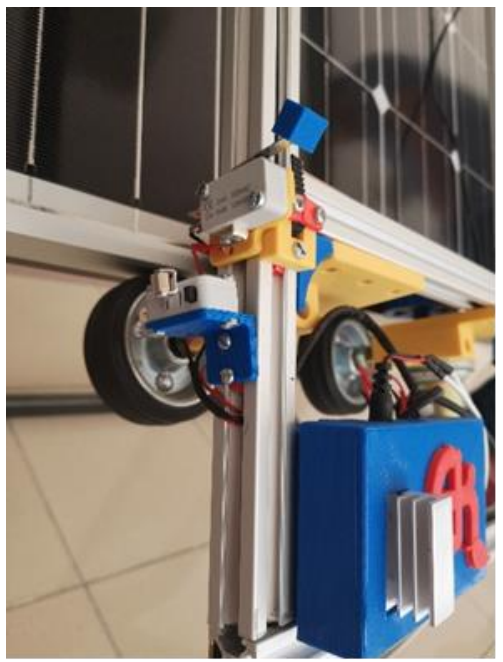

(a)

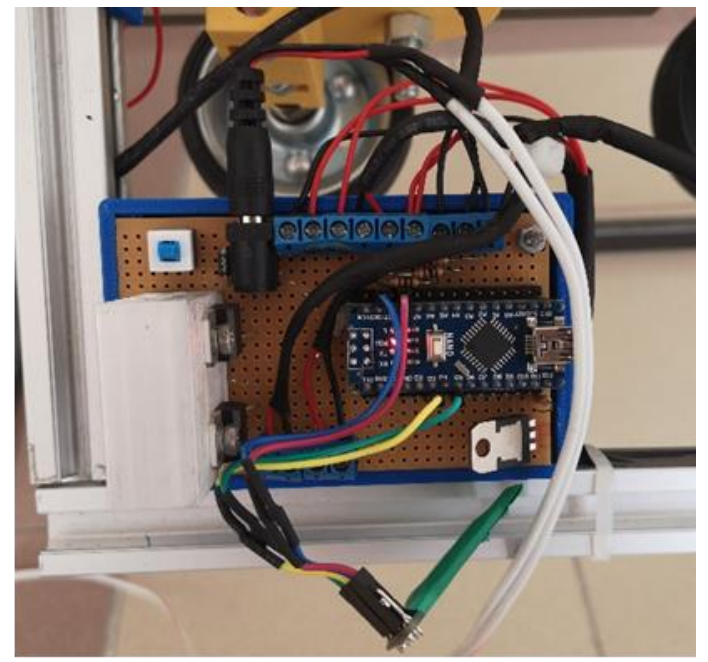

(b)

Figure 5. Control unit.

\section{Results, Discussion and Recommendations}

As a conclusion, we presented a microcontroller based SPCR system which is cost and lightweight effective. The proposed system reduces the effect of dusting on the output power of the PV panels. This system is deigned in short time period and also, the tests are likewise. However, more testing of the device will be done to ensure the reliability.

As future aspects, we want to make some improvements on our project. Some of these developments are to provide shortest cleaining time, minimum water and electricity storage requirements. The cleaning time can be reduced by changing brush type. Also, for the next version of the device, a light dedection circuit will be included to the system for day and night dedection. To avoid placing birds on PV panels, flashing leds and a moving structure will be considered. In order to wait for the bluetooth data used for activation of the system, an automatic periodical time (three or two times per day) activation may be designed.

\section{References}

[1] Available from: https://www.enerji.gov.tr/en-US/Pages/Solar

[2] Available from: https://www.teias.gov.tr/sites/default/files/2018-03/kurulu guc.pdf

[3] Mondal, A. K., \& Bansal, K. (2015). Structural analysis of solar panel cleaning robotic arm. Current Science, 108(6), 1047-1052.

[4] Faranda, R., \& Leva, S. (2008). Energy comparison of MPPT techniques for PV Systems. WSEAS transactions on power systems, 3(6), 446-455.

[5] Elgendy, M. A., Zahawi, B., \& Atkinson, D. J. (2011). Assessment of perturb and observe MPPT algorithm implementation techniques for PV pumping applications. IEEE transactions on sustainable energy, 3(1), 21-33.

[6] Safari, A., \& Mekhilef, S. (2010). Simulation and hardware implementation of incremental conductance MPPT with direct control method using cuk converter. IEEE transactions on industrial electronics, 58(4), 1154-1161.

[7] Patel, H., \& Agarwal, V. (2008). MATLAB-based modeling to study the effects of partial shading on PV array characteristics. IEEE transactions on energy conversion, 23(1), 302-310.

[8] Ramabadran, R., \& Mathur, B. (2009). Effect of shading on series and parallel connected solar PV modules. Modern Applied Science, 3(10), 32-41.

[9] Rani, B. I., Ilango, G. S., \& Nagamani, C. (2013). Enhanced power generation from PV array under partial shading conditions by shade dispersion using Su Do Ku configuration. IEEE Transactions on sustainable energy, 4(3), 594-601.

[10] Sulaiman, S. A., Singh, A. K., Mokhtar, M. M. M., \& Bou-Rabee, M. A. (2014). Influence of dirt accumulation on performance of PV panels. Energy Procedia, 50, 50-56.

[11] Adinoyi, M. J., \& Said, S. A. (2013). Effect of dust accumulation on the power outputs of solar photovoltaic modules. Renewable energy, 60, 633-636.

[12] Mani, M., \& Pillai, R. (2010). Impact of dust on solar photovoltaic (PV) performance: Research status, challenges and recommendations. Renewable and sustainable energy reviews, 14(9), 3124-3131.

[13] Jiang, H., Lu, L., \& Sun, K. (2011). Experimental investigation of the impact of airborne dust deposition on the performance of solar photovoltaic (PV) modules. Atmospheric environment, 45(25), 4299-4304.

[14] Avaiable from: https://www.serbot.ch/en/solar-panels-cleaning/gekko-solar-robot

[15] Available from: https://www.serbot.ch/en/solar-panels-cleaning/gekko-solar-farm-robot

[16] Available from: https://www.aerialpower.com/solarbrush/ 
[17] Hardt, M., Martınez, D., González, A., Garrido, C., Aladren, S., Villa, J. R., \& Saenz, J. (2011, September). HECTOR-Heliostat Cleaning Team-Oriented Robot. In Solar-PACES 2011 Conference, Granada, Spain, September (pp. 20-23).

[18] Available from: https://www.greentechmedia.com/articles/read/sunpower-cleans-up-solar-with-acquisiton-ofgreenbotics\#gs.o6xruc

[19] Available from: https://www.solarpanelcleaningsystems.com/solar-panel-cleaning-services.html

[20] Al-Dhaheri, S., Lamont, L., El Chaar, L., \& Al-Ameri, O. (2010, April). Automated design for boosting photovoltaic (PV) performance offshore. In Proceedings of 2010 transmission and distribution conference and exposition; 2010; Abu Dhabi.

[21] Al-Qubaisi, E. M., Al-Ameri, M. A., Al-Obaidi, A. A., Rabia, M. F., El-Chaar, L., \& Lamont, L. A. (2009, November). Microcontroller based dust cleaning system for a standalone photovoltaic system. In 2009 International Conference on Electric Power and Energy Conversion Systems (EPECS) (pp. 1-6). IEEE.

[22] Jaradat, M. A., Tauseef, M., Altaf, Y., Saab, R., Adel, H., Yousuf, N., \& Zurigat, Y. H. (2015, December). A fully portable robot system for cleaning solar panels. In 2015 10th International Symposium on Mechatronics and its Applications (ISMA) (pp. 1-6). IEEE.

[23] Anderson, M., Grandy, A., Hastie, J., SWEEZEY, A., RANKY, R., MAVROIDIS, C., \& MARKOPOULOS, Y. P. (2010). Robotic device for cleaning photovoltaic panel arrays. In Mobile Robotics: Solutions and Challenges (pp. 367-377).

[24] Lamont, L. A., \& El Chaar, L. (2011). Enhancement of a stand-alone photovoltaic system's performance: Reduction of soft and hard shading. Renewable Energy, 36(4), 1306-1310.

[25] Mondal, A. K., \& Bansal, K. (2015). A brief history and future aspects in automatic cleaning systems for solar photovoltaic panels. Advanced Robotics, 29(8), 515-524.

[26] Mondal, A. K., \& Bansal, K. (2015). Structural analysis of solar panel cleaning robotic arm. Current Science, 108(6), $1047-1052$.

[27] Patil, P. A., Bagi, J. S., \& Wagh, M. M. (2017, August). A review on cleaning mechanism of solar photovoltaic panel. In 2017 International Conference on Energy, Communication, Data Analytics and Soft Computing (ICECDS) (pp. 250-256). IEEE.

[28] Available from: https://www.arduino.cc/en/uploads/Main/ArduinoNanoManual23.pdf

[29] Available from: https://www.arduino.cc/en/main/software 